\title{
Peculiarities of Creating Foreign Students' Lexical Competence
}

\author{
Aigul Eskermesovna Sadenova (Corresponding author) \\ Al-Farabi Kazakh National University, 71, Al-Farabi ave., Almaty, 050006, Kazakhstan \\ E-mail: sadenova.aigul@mail.ru \\ Raushan Makanovna Yesbulatova \\ Al-Farabi Kazakh National University, 71, Al-Farabi ave., Almaty, 050006, Kazakhstan \\ Farida Orazakynkyzy \\ Abai Kazakh National Pedagogika University , 71, Dostyk ave., Almaty, 050010, Kazakhstan
}

Saule Anuar

International Kazakh-Chinese Language College, 45A, 5th Microregion, Almaty, 050040, Kazakhstan

\author{
Received: 11-06-2016 \\ Accepted: 05-09-2016 \\ Advance Access Published: November 2016 \\ Published: 02-01-2017 \\ doi:10.7575/aiac.ijalel.v.6n.1p.73 \\ URL: http://dx.doi.org/10.7575/aiac.ijalel.v.6n.1p.73
}

\begin{abstract}
Teaching of vocabulary includes several aspects of teaching content: linguistic, methodological and psychological. Teaching of vocabulary is a process which is inextricably entwined with understanding relations between new words and phonetic and grammar aspects of the language. On the one hand, simultaneous learning of two languages complicates the tasks set to the students, but, on the other hand, it simplifies the process. The complexity is in the scope of vocabulary to be remembered, as well as in the differences between grammar structures used in Russian and Kazakh. The simplification is in the fact that students are fully aware that lexical competence is formed gradually, and that every language has its lexical base required at the initial stage, and that such base is to be developed for mastering a specific language. Before identifying the methods of vocabulary semantization in the course of teaching a language to foreign students, students shall be offered active vocabulary, used to express their ideas orally and in written form, and passive vocabulary, used to perceive oral and written information. It is not possible to teach semantics only. It is necessary to create paradigmatic, syntactic and associative relations. The formation of lexical skills is connected with the solidity of vocabulary retention. In order to ensure reinforcement of the vocabulary learnt, the students shall be offered exercises contributing to the development of their skills of using vocabulary in listening, speaking, reading and writing. All above mentioned types of vocabulary semantization constitute a unified whole. Different ways of semantization are set forth for methodological purposes, to facilitate the achievement of the desired result. Translation and non-translation techniques for vocabulary presentation, as well as some tips and exercises, are given. The use of basic vocabulary at elementary and advanced levels is suggested. Certain methods for the semantization of vocabulary units are recommended.
\end{abstract}

Keywords: vocabulary, semantization, word building, translation and non-translation methods, vocabulary unit, translation and non-translation techniques

\section{Introduction \\ 1.1 Problem statement and objectives of the research}

Vocabulary, along with grammar is the foundation of any language. With the help of the vocabulary, information is received and transferred. With the accumulation of the vocabulary and the enrichment of the dictionary of foreign students begins mastery of speech, that's why the process of mastering of lexical units of active and receptive inferior limits should be considered as an informational and educational process related to the acquisition (accumulation), storage and use of lexical knowledge and lexical units. In this regard, the mastery of vocabulary to use it in speech is one of the main problems of foreign students learning a foreign language in HEI. Serious consideration should be given to the work on vocabulary in the classroom. At the same time mastering of lexical units of active and receptive character should be based on different types of competence of foreign students (communicative, linguistic, sociolinguistic, discursive, socio-cultural, etc.).

The desire to understand the processes of gaining foreign speech by older foreign men gave impetus to research in the field of the most effective approaches to teaching this age group. We, following authors of the traditional and intensive directions in language training, make an attempt to resolve the issue of how to help a foreign adult to master a foreign 
speech practically in the same degree of freedom, as if it is his mother tongue. We try to consider the process of learning the language with the positions of the parties directly involved in this process.

It is necessary to substantiate theoretically, to develop and put into practice a system of lexical directed exercises as a whole and its component parts, which form the lexical competence of foreign students, a significant place in which is occupied the lexical component, and optimize the assimilation of vocabulary. This determines the relevance of the study.

As the object of our research is the formation process of the lexical competence by foreign students. The subject of the study is to determine the role and characteristics of the formation of the lexical competence by foreign students. The main objective of the study is the theoretical basis of approaches to the formation of lexical competence by foreign students and development of a system of lexical of exercises, based on the methodical sequence of stages in the formation of lexical competence and linguistic difficulties, experienced by students in learning vocabulary. The leading role in the process of achieving this goal is taken by language competence, which is based on lexical and grammatical skills and abilities, because any communication becomes impossible without the language competence. Only language competence provides an understanding of the semantic segments of the speech, organized in accordance with the norms of a foreign language on the basis of a decent amount of knowledge.

With this aim we have developed an integrative theory of acquisition of non-native language - theoretical and methodological base of communicative and cognitive model of acquisition of non-native language and technology of teaching the second language in the term of its functioning. Awareness of the importance and the need for knowledge of Kazakh, Russian, as well as one or more foreign languages in Kazakhstan becomes the basis for the creation of such educational technologies, which have contributed to keeping an interest and motivation to learn languages.

\subsection{Justification of the research subject and technique}

Research of the process of mastering second language by adult foreign users is based on the justification of communicative-cognitive model of assimilation of non-native language. Under the communicative-cognitive model of assimilation of non-native language we understand the description of the mechanism for acquisition non-native language as a set of processes of interaction of all components of the model, that determine the assimilation of nonnative language as a cognitive activity, in order to demonstrate the positive impact of an integrative method, stimulating and optimizing a cognitive activity of an adult foreign user in the process of an acquisition of the target language. Communicative-cognitive model of acquisition non-native language offers a description of communicative and cognitive activity of the secondary language personality and is the optimal form of explication of inaccessible to direct study of latent processes of cognitive activity. Implementation of communicative-cognitive activity is an activity that expresses and provides thought processes, their structure and dynamics in the process of cognition and communication.

Word is the key unit of study, so a powerful impetus to the development of modern methodology is the reliance on data of linguistic research of vocabulary, and primarily on the data of cognitive linguistics, which let us to give a new vision of the entire system of teaching foreign language as a foreign language and to rethink the methodology of teaching vocabulary to foreign students.

At the present stage of development of the theory and methods of teaching the Kazakh language and Russian language as a foreign development of linguacognitive concept of teaching vocabulary to foreigners, which is the result of a new methodological interpretation of all components of a system of teaching vocabulary from the standpoint of a linguacognitive approach, is an actual scientific problem, the solution of which will contribute to both deepen and expansion of theoretical knowledge in the field of methods of teaching vocabulary, and an improvement of the effectiveness of teaching the Kazakh language and Russian language as a foreign language.

To achieve the objectives the following research methods are used: the theoretical analysis and the theory and methods of teaching non-native language; functional-communicative, structural-semantic, cognitive-propositional, contextual method; integrative method of describing the derivative vocabulary based on research in the field of modern linguistics, psycholinguistics, cognitive science and lingua-cultural studies; method of monitoring the receptive and productive speech activities of foreign students in order to determine the degree of awareness of mastering of derivative words by them.

Nowadays, the new conditions of society development make the system of higher education face new challenges of creating a whole new level of training qualified specialists, which would contribute to their development and becoming creative personalities possessing their own thinking style, as well as the capability to solve the tasks they face creatively and on their own. Intentional development and systematic reforming of higher education implies a special role of language education, developing communicative competence of a person capable of using a foreign language as a means of communication. E.I. Passov considers a foreign language as a "productive power", and the foreign language literacy - as an "economic category" (Passov, 2007, p.17).

The humanistic trend in the society development is inextricably connected with the idea of "a developing personality in a developing world". The solution of this problem depends directly on the level of education - the crucial component of the human culture.

One of the most important and essential basic international requirements set up by the European Council is the obligatory command of several foreign languages. A foreign language can serve as the means of bringing a person to 
universal, global values, as well as of forming communicative skills and the ability to interact with representatives of other cultures within the universe.

The fact that human resources, which act as the main factor of economic and social progress, "are becoming the fortune of the society in the conditions of modern market economy and information technology development" is more and more understood (Galsakova, \& Gez, 2006, p. 7). When solving this issue, the highest value is placed on learning foreign languages.

\section{Formation of the system of lexical competence}

\subsection{Communicative competence}

Solving the problem of communicative competence of foreign students becomes especially relevant in our multinational country. This is determined by the orientation of today's methods of teaching foreign languages to practical mastering of foreign languages, which provides for the change from the conscious acquisition of the language units to their use in speech situations which are as close to natural communication environment as possible. Practical command of language is understood to mean a person's command of all types of speech activity: listening, speaking, reading, and writing - in the most important communication areas. In other words, the communicative approach is characterized by putting a premium on the formation of communication skills as the overarching objective of the teaching process.

Resulting in class lexical knowledge, skills and abilities are to provide awareness of the specificity of expression of thoughts, feelings and communicative intentions by means of the target language.

Achievement a high level of development of lexical competence is shown in the fact that a person can easily use a large lexical vocabulary both in direct and indirect communication, using set phrases, proverbs and sayings adequately (Kommunikatsiya i obuchenie inostrannym yazykam, 1970, p. 53) typical for the speech of native speakers. One has to agree with Erica B. Michael, who complements the definition of lexical competence, including in the list of characteristics a confident knowledge and usage of polysemy of the target language, different contexts of use of lexical units, idioms, slang, humorous expressions and cultural-marked lexicon (Kommunikatsiya i obuchenie inostrannym yazykam 1970, p. 31). However, despite the diversity of the presented definitions, this concept would be incomplete if it covered only lexical knowledge, skills and abilities, so, of course, lexical competence, being a complex structural formation, in its composition also includes the language, speech experience and personal qualities of students (Common European Framework of Reference for Languages, 2005). According to A.N. Shamov, the formation of lexical competence begins first and foremost with the accumulation of empirical knowledge - observation of the functioning of the lexical units in different communicative contexts (oral and written) (Shamov, 2007). At this stage, the presentation and semantization of a new vocabulary are organized - students get an idea of the sound and graphic image of a lexical unit, links between the foreign word and its meaning are formed. Students acquire skills in the identification of lexical units in the presented communicative situations.

Lexical competence is a complex structural formation. According to the definition of A.N. Shamov, lexical competence "based on lexical knowledge, skills, abilities, and personal language and speech experience a person's ability to determine the contextual meaning of a word, to compare the volume of its meanings in two languages, to understand the structure of the meaning of a word and highlight a specific national within the meaning of the word" (Shamov, 2005, p. 247).

According to I.L. Perestoronina, under the lexical competence should be understood "a set of language skills in the field of vocabulary, also language skills and abilities, mastery of which allow you to make semantically correct choice of lexical units in the linguistic context, according to the language norms of the studied language" (Perestoronina, 2003, p. $26-27)$.

Teaching objectives, its content, levels of knowledge and skills are determined vie competences of various types. A competence is understood to mean the combination of the knowledge and skills which are formed in the course of teaching language and contribute to mastering it. When teaching the Russian language to foreign students (irrespective of the teaching level), the formation of the communicative competence is the main objective (Uspenskiy, 2004, p. 74). Some scientists equal communicative competence to speech competence (Uspenskiy, 2004), others make a distinction between these notions (Mitrofanova, 1990), still others define communicative competence as a combination of linguistic, sociolinguistic, discursive, strategic, social, sociocultural competences (Shchukin, 2007).

Let us consider those types of competences which have a direct relation to learning foreign languages. Language competence constitutes practical mastering of the language system material. Linguistic competence comprises knowledge of the basics of the foreign language science, learning the definitions of the training course, as well as the formation of the language learning skills for working with language material. Communicative competence includes knowledge and skills required for understanding someone's and generating one's own speech behavior programs appropriate to the objectives, areas and situations of communication. It also includes knowing the basic notions of the speech linguistics, text analysis skills and the communicative skills themselves - verbal communication skills as applied to various communicative areas and situations with account for the addressee and the speech style.

The formation of linguistic and communicative competences is of equal importance when teaching a foreign language. With the growing requirements to the quality of specialists training, these competences have become essential qualifications. Communicative competence is the leading competence in the above list, whereas it is, first of all, the key competence which determines the language command level. According to A.K. Krupchenko and A.N. Kuznetsov, 
communicativeness is the ability of speech to express definite content with the aim to satisfy specific needs of communicators (Krupchenko, 2015, p. 167).

The notion of "communicative competence" includes the following indicators:

1) awareness of the linguistic theory, understanding it as a system of rules and general guidelines regulating the use of the means of language in speech;

2) knowledge of the speech study theory, good command of the basic types of speech activity;

3) good command of basic language (identify, classify, etc.) and speech (select, update, etc.) skills;

4) ability to analyze the speech situation and select the speech behavior program (verbal and non-verbal) accordingly.

Therefore, the aim of teaching English under the bilingualism conditions in our country is connected with the formation of communicative competence - one of the most crucial categories of linguo-didactics and the basic cultural component. This determines the content of foreign language teaching which is oriented to:

- creating the skills of setting and solving language tasks (competency) - self-management;

- mastering linguistic knowledge (informational competence);

- using language facts in oral and written communication.

Today, the linguistic principle, as the leading principle of teaching, gives way to the communicative principle both, in theory and practice.

The aim of teaching students at higher educational institutions is the formation of their communicative competence, i.e. a set of speech behavior programs and their implementation depending on a person's ability to figure out the communication environment. Such ability is based on the professional communication principle which simulates the conditions of professional relationships. Teaching focus on the formation of competence in solving issues will allow to prevent theory separation from the practical use of language phenomena in speech and, therefore, requires thorough understanding of the language theory. Besides, in the course of teaching, the formation of awareness, a person's social qualities, social behavior motives, typical for the society of the country of the language learnt, takes place (Passov, 2010, p. 30).

Modern functioning of a foreign language as the language of international communication is closely connected with the world culture and civilization. It is important to organize the teaching process in such a way as to enable students to join the world culture through the use of a foreign language. It is essential to create such culture model in classes which would contribute to spiritual improvement on the basis of the dialogues between the native and the world cultures. The component parts of such model can include: reality represented objectively (photographs, figures, drawings); objectively and verbally (TV programs, performances, movies); by fiction; educational non-fiction texts of deductive content, as well as by idioms, sayings, outstanding people's quotes. The human's cultural involvement does not happen in the course of the language learning only. It is also influenced by what we read, listen to, see, as well as by the communication situation the students are immersed into. The needs analysis model developed by J. Munby makes it possible to obtain a comprehensive profile of students' needs: communicative objectives, communication environment, communication means, communicative skills (types of speech activities), etc. (Munby, 1978, p. 55).

The communicative component of the content element implies the selection of communication situations which maintain external, internal and didactic authenticity (Wolpers et al., 2010, p. 111), as well as special purpose texts (written texts, audio texts) of communicative value.

One of the aids creating a developing speech environment is a text. The text has the following functions: communicative, sense-making and creative. Texts shall contain grammar practicing material, aesthetic value and educative intention (Djik, T.A. Van, 1988; Brown, 1983; Van Ek, 1990; Kubriakova, 1997).

The system of assignments used in foreign language classes implies the creation of a ready-made educational product: writing of a well-reasoned essay, creative work oriented to the communication objectives and tasks. At the preparatory stage, students perform a comprehensive text analysis, linguistic analysis and comparative analysis. Identifying the topic, idea, style, type of speech does not become an objective. It is only a means to achieve a certain objective.

The enhancement of the students' speech culture is not deemed possible without the formation of definite skills ensuring the production of an utterance:

- $\quad$ skills to understand and figure out the speech environment quite well -objective of communication, the topic and the main idea of the utterance, the addressee, place of communication, scope of utterance, to design the idea of the future speech product;

- $\quad$ skills to collect material, using various sources, systemize it, make up a plan for the future utterance oriented to the speech product idea, as per the idea of the future speech product;

- skills to use various styles and types of speech, various language means, select them with account for all components of the speech environment as per the idea of the future speech product;

- skills to see the listener's response during oral communication, compare what is uttered with the idea of the utterance and correct one's speech. 
In order to improve the process of teaching foreign languages, integrative technologies are being implemented. The use of these technologies ensures the solution of practical tasks not only of colloquial nature, but also of professional and sociocultural nature (evaluation of human behavior in different situations, understanding pieces of art, etc.). Language teaching, reasonably organized in terms of methodology, contributes to the perception and understanding of information processes in the course of listening, reading, writing, and in mass media, etc., which allows to learn to use both verbal and non-verbal means of communication, master competence in business communication (skills to conduct business negotiations, keep business correspondence, knowledge and realia consideration). We consider that communication shall not be restricted to learning standard forms only. Besides, the real necessity for students' learning to understand national and regional specificity is observed.

The choice of methods and techniques of teaching foreign languages is significantly affected by social and political, mental factors, which put a premium on certain objectives of language mastering. In addition, problem methods are widely used: discussions, analysis of a specific situation. The pedagogy of cooperation is given high priority, which meets today's social order. Today, the forms and methods of teaching shall be oriented to opening a personality forming potential as means of educating and bringing up a humanistic personality able to universally communicate, cooperate, and carry on intercultural dialogue. In this regard, such ideas as pedagogy of cooperation, formulated by native educators, as well as the idea of a challenging objective, idea of support, self-analysis, free choice, idea of advance, etc., are deemed the most useful.

The notion of the system is a basic notion in the communicative and integrative approach and is defined as a combination of basic elements of the teaching process. According to the communicative and integrative approach, this notion includes the following elements: objectives, tasks, content, approach to teaching, principles, methods, teaching aids, organizational forms of each stage. All above mentioned elements of the system are in a certain hierarchic dependence, where the dominant role belongs to the objective, motive, and teaching needs which are formed under the influence of the environment and social need.

The approach constitutes a methodological basis for the teaching model. In the scientific methodological literature, there are distinguished such general approaches as: behavioral, inductive and conscious, cognitive, notional, level, etc.

The practiced communicative and integrative approach is aimed at the implementation of the needs of the students, who act as consumers with regard to the subject and the system of teaching. The strategy of this approach provides for the account of the set addressee on an integrated basis, by the internal integration - the synthesis of the language, speech and pragmatic material, and the external integration - the intersubject coordination of disciplines. Our educational experience proves that the environmental (social) approach contributes significantly to the shift from an isolated, autonomous learning of certain linguistic aspects, in spite of the internal systematization and orderliness of the semantics, to the integrated learning of real conditions of the language functioning.

The formation of the students' communicative competence provides for the acquisition of linguistic knowledge, speech skills, combined with extralinguistic knowledge about the rules, standards, stereotypes of communication and communicative behavior, the readiness to apply them in various areas of language communication.

Communicative competence, being the leading and ultimate objective of the students' and graduate students' learning and cognitive activity in the course of their mastering a foreign language, constitutes a complex psycholinguistic formation, the essential elements of which are language, speech and pragmatic competences. Level structuring of the communicative competence (language, speech, pragmatic) under the conditions of implementing the communicative and integrative teaching technology (CITT) provides the possibility to use the language not only as a means of communication, but also as a means of familiarizing oneself with the world culture, the culture of the country where the language learnt is native, as well as of the country where the language is learnt.

The efficiency of the communicative competence formation is determined not only by the training level (awareness of the language system and the ways of its implementation in speech activity), but also by the degree of the students' familiarization with the cultural and educational environment.

In the course of teaching a foreign language, it is necessary to manage the natural communicative activity of the students under the conditions of the language environment, which allows to organize and coordinate independent development of communicative skills, as well as to combine teaching with mastering.

The ultimate role of teaching a language is determined by the role it, being the most important means of communication and understanding the surrounding world, plays in each person's life and in the whole society. Students need a foreign language as both a means of obtaining knowledge, modern information, and a means of enhancing their professional communication with patients and specialists in the course of performing joint scientific activities. A foreign language plays a crucial role not only in training highly qualified specialists, but also in their spiritual and moral development. Teaching a foreign language boosts the creation of the communicative competence, brings up a linguistic persona capable of professional business cross-cultural communication, striving for self-development and self-education, capable of creative thinking. 
Language is not only a system of signs. It is also a historically developed form of the people's culture. Cultivated speech has always helped people achieve understanding both in production activities, and in spiritual communication.

In order to master a foreign language, one should understand that native speakers of the language learnt are also bearers of a foreign culture. One should learn to communicate with such natives within the framework of their culture, and to be exact, master the cross-cultural communication. Cross-cultural communication is a process of verbal and non-verbal communication between natives speaking different languages and bearing different cultures. Cross-cultural communication ensuring mutual understanding between the speakers requires from the people, mastering a foreign language communicative activity, sufficient background knowledge, sociocultural background, within the context of which the language learnt exists (Baryshnikov, 2000).

The key to the communication between people is in their striving to understand each other. Each culture is formed in accordance with its basic characteristics, one of which is the language. According to S.G. Ter-Minasova, by learning one foreign word a person kind of extracts a piece of a puzzle from a strange picture, not completely known to him yet, and tries to reconcile it with the picture of the world existing in his consciousness, which has been set by his native language (Ter-Minasova, 2008, p. 48).

Students from over 35 countries of the world have been trained at the Pre-University Training Faculty of Al-Farabi Kazakh National University for 30 years of the faculty existence. In order to achieve the set goals, they learn Russian and Kazakh. However, learning phonetic, lexical, grammatical phenomena with no regard for cultural phenomena does not provide the desired result. When creating students' communicative competence, a teacher has to simultaneously form their sociocultural competence, building a new world picture which does not always coincide with the native one.

When starting classes, a teacher shall define what information about the country will be necessary for foreign students for proper understanding of what is written or heard; what information is to be brought to their attention in order to satisfy their cognitive curiosity; in what sequence shall such material be better offered to the students during the whole teaching process and in each class.

Students are divided into language groups with regard for the specialty chosen by them, as many of them intend to proceed with training at the universities of Kazakhstan, as well as based on the entrance tests results. Students are united into international groups with no regard for their native language. Certainly, it has its own advantages, as the students do not only learn Russian, but also get acquainted with the representatives of another culture. Under such conditions, high responsibility rests on the teacher of Russian as a foreign language: to create, in the course of teaching process, all conditions required for mastering the language successfully. Student groups include people of different age and education level, who have come from different countries, and the relationships established between them will determine their success, achievements and mistakes.

Successful mastering of a language is facilitated not only by good memory, language aptitude, etc., but also by friendship between completely different people.

The richness of any language is made up by its lexical and phraseological fund accumulated during many centuries and reflecting the peculiarities of life and household, traditions and people's worldview. Folk wisdom is an international phenomenon. It often appears that a proverb from the student's native language has almost the same sense that the proverb suggested by the teacher, and comparing two phrases of similar meaning gives a good reason for talking about the customs of two countries. Proverbs, sayings, phraseological units are easily remembered and influence the behavior and the inward of a person. However, the proverbs and sayings suggested to foreign students shall be subject to strict selection. Their relevance, frequency of use, educational and methodological expediency shall be regarded. Based on the above, at the lessons of Russian, teachers shall introduce foreign students to the proverbs, sayings, phraseological units which can tell about the traditions and customs, about household, human nature and emotions. Understanding between people can be achieved only when students do not only master language knowledge and skills, but also when they familiarize themselves with the culture of other nations.

Teachers of Russian and Kazakh as foreign languages, working in international classrooms, know that teaching Russian or Kazakh to a Japanese or to an Arab is not the same as teaching them to an American or a Korean, whereas representatives of different countries have their own idea of the world. For instance, when having a class with Korean or Vietnamese students, one should remember that, when, for example, explaining the idiom "собаку съел" ("to еat a dog" - to know something in and out), a linguo-cross-cultural comment shall be provided. Such comment shall explain the figurative meaning of this language unit and emphasize the total absence of its relation to the process of eating this "human friend'. Such comment is not required when teaching students from Europe, America and most of other countries.

When teaching Russian as a foreign language, the integration of the culture requires its study on a comparative basis, when one culture meets another one and, as a result, its specificity shows up. It is clear that culture can act as both a means of communication and a means of separation. Separation takes place in the event when the partners participating in the communication do not understand the specific peculiarities on verbal and non-verbal behavior, and the cultural difference between them is too big.

In order to ensure the possibility of communicating, a teacher should select such material for the classes which would contribute to understanding the traits of the national lifestyle better. However, a teacher should not forget that foreign 
students can take rare facts for frequent ones, occasional facts - for common ones. The teaching process shall be organized with account for the students' native language and culture. Knowing the native culture of the students taught allows the teacher to predict possible cases of inappropriate behavior of the students when communicating in Russian. Such cases can be brought about by misunderstanding of certain local life realia. Thus, the teacher is able to take measures for preventing cross-cultural interference. Besides, knowing the students' native culture effects the teacher's behavior, who shall behave in such a way as not to hurt the students' national dignity.

Thus, it's better to tell a student from an Arabic country that he did not understand a rule. A man will never put up with being accused of something, especially if it is a man from an Arabic country. Arabs have a streak of high self-esteem. Students from Latin America shall be subject to more frequent checking. As for the students from African countries, they also differ. Students from Mali are highly-organized and disciplined as against the students from Nigeria, but they are all very touchy. Chinese students are extremely hard working, but they do not understand local jokes; therefore, it's not so easy to raise a smile on their faces. As a rule, they do not tell about themselves. Telling about a family is a cliché, text retelling - learning of certain phrases by heart. They like to read texts out loud and in unison. Instead, they enjoy telling about their centuries-old culture. They like it very much when students from other countries show interest to their country, traditions and customs. Chinese students are pleased to do written tasks; their favorite table-top book is a dictionary. They prefer to look up each word in a dictionary, to find out the accurate translation.

Recently, Chinese students have been studying at our faculty for two years, as it's much more difficult for them to learn Russian and Kazakh, than for the students from other countries. They typically make friends with their countrymen, though they also get on well with other students as they are quite tactful. It is a known fact that the distance between a teacher and a student from Latin America is shorter than between a teacher and a Korean student. Sometimes a teacher has to interrupt an uninhibited student from Turkey, while, at the same time, has to drag out phrases or a remark from other students.

Therefore, the problem of cross-cultural communication in teaching Russian as a foreign language cannot be solved easily for the representatives of every region have their own peculiarities, disregard to which does not allow to organize the teaching process properly. A teacher plays the leading role here. In order to provide students with relevant knowledge, a teacher is not only to be a competent specialist, but also a good actor and a sophisticated diplomat.

For foreign students involved in cross-cultural communication, starting from its first stages, there appears a tendency for a "two-culture dialogue" - a native culture and a studied culture. Foreign students get information about different aspects of the life in the country of the language learnt. Having no knowledge about the country, its traditions and customs, it will be problematic for a foreign student to perceive the language learnt. Discrepancies between the native and the studied realities result in the occurrence of mistakes like "записаться в университет" ("get enrolled in the University”), “купить в аптеке карандаши” (“to buy pencils at a drugstore”), “килограмм яиц” (“a kilo of eggs”) and other mistakes, as the students transfer the facts of their native culture to the foreign culture.

A teacher of Russian and Kazakh as foreign languages shall understand that foreign students already have fully formed ideas of their people and other peoples. Therefore, it is crucial to teach them to see differences between cultures, catch peculiarities of other culture and overcome stereotypes. When teaching Russian and Kazakh as foreign languages, one should remember the teaching process will be more effective if foreign students know the culture of the country, the language of which they are learning. Having come to a foreign country, foreign students do not only learn the language the local population is speaking, but also join national values, learn to understand basic features of the national character, as well as the peculiarities of the natives' view of life.

In today's teaching environment, when one group includes representatives of different countries, who have their own peculiarities of national character and thinking, the issue of cross-cultural communication is of key importance. In this respect, a teacher shall teach students to respect the uniqueness of each culture, to be tolerant to differing behavior of the students from other countries and to be flexible in their response. Common interaction standards shall be worked out. Such standards shall take into consideration traditions and customs of the country the language of which is learnt.

The real conditions of cross-cultural communication allow to introduce students to cross-cultural dialogue, form their sociocultural behavior and attitude to the world.

Vocabulary occupies a special place in teaching Russian and Kazakh to foreign students, as, when combined with grammar and phonetics, it allows to conduct oral and written communication. Teaching of vocabulary includes several aspects of the teaching content: linguistic, methodological and psychological. Teaching of vocabulary constitutes a process which is inextricably connected with understanding the relations between new words, as well as phonetic and grammar aspect of the language.

Foreign students learning Russian at the Pre-University Training Faculty of Al-Farabi Kazakh National University have to learn Kazakh compulsorily, just like foreign students learning Kazakh have to learn Russian.

Simultaneous learning of two languages complicates the tasks set to the students, but, on the other hand, it simplifies the process. The complexity is in the scope of vocabulary to be remembered, as well as in the differences between grammar structures used in Russian and Kazakh. The simplification is in the fact that students are fully aware that lexical competence is formed gradually, and that every language has its lexical base required at the initial stage, and that such base is to be developed for mastering this or that language. 
2.3.1 Lexical skills: word use and word building

Each word of the Russian language is changed in accordance with the laws of the language: nouns and adjectives are declined, verbs are conjugated. Lexical units form semantic and syntagmatic relations, reveal associative relations. A word is learnt not in isolation, but in interrelation with other words within a sentence or a text. Foreigners learning Russian create a stable semantic field, the volume of which is not static and is characterized by dynamics. The same problems are encountered by the students learning Kazakh.

The language teaching methodology distinguishes vocabulary required for expressing ideas orally and in written form, and passive vocabulary required to perceive oral and written information.

The base for foreign students' mastering of vocabulary is laid already at the initial stage. It is a minimum of words and collocations required for understanding grammar and speech development. The minimum includes approximately 1200 units which are used in educational and household environment. This base is essential for gradual further expansion of the students' vocabulary.

Correct word use by the students is formed in semantically correct collocations which differ from the standards of the native language. Speech practice, in the process of which conversational skills are reinforced, is absolutely required. Speech model helps students to build sentences in compliance with the rules of the Russian language, as literary translation from the native language does not always allow to make a speech (Ignatova, 2012, p. 77).

High repetition of the same vocabulary units at the initial stage contributes to better remembering of words. A base for expanding students' vocabulary is created. In the course of communication, two sides of speech activity are highlighted: understanding foreign speech and expressing own ideas. In order to implement these sides, which constitute a single process, the vocabulary varying in volume and content is used.

Every person has a passive vocabulary understood by him but not used in speech. Active vocabulary is more limited, but is fluently used by a person.

The volume of active and passive vocabulary in the native language depends on the person's educational and cultural level.

In order to build lexical skills it is extremely important to determine a stable semantic field required specifically for this group of students.

Lexical and phraseological combinability is nation specific (and not versatile), as is claimed by S.G. Ter-Minasova. It is typical to the given specific word in the given language. This specific nature becomes evident upon comparing languages only, in the same manner that the native culture is revealed upon clashing on the foreign culture (TerMinasova, 2008).

\subsubsection{Ways of lexical units semantization}

Lexical competence comprises the ability to quickly understand words, select a word depending on its semantic, stylistic and sociocultural characteristics. The problems of communicating with native speakers can arise at the first attempt to communicate. Students shall be oriented to the gradual elimination of the problems, long-lasting communication with natives, mastering grammar in inextricable connection with vocabulary, creation of sociocultural competence. The main prerequisite for the development of foreign language competence is the communicative orientation of training. It can be created via the use of a specially developed system of communicative exercises which can be divided into three types as per basic levels of managing educational communicative activity - hard, partial and minimum management (Kitaigorodskaya, 2009).

The essence of the strategic component is in teaching students to discover the meanings of unknown lexical units on their own and to reinforce the understood lexical material in their memory on their own, which, thus, implies the formation of lexical strategies with the students taught, in particular social strategies (mastering lexical units by interacting with other people), mnemonic strategies (mastering lexical units by establishing relations with appropriate synonyms, antonyms, personal experience, etc.), cognitive strategies (mastering lexical units by verbal and graphic repetition), metacognitive strategies (mastering lexical units using foreign media resources on their own initiative, revising vocabulary on their own, etc.) (Schmitt, 2000, pp. 135-136).

Words shall be introduced in a certain context. This creates associative relations which improves the process of vocabulary remembering. There are distinguished three stages of teaching lexical skills:

1) stage of introduction and semantization of a new word, its reproduction;

2) stage of situational practicing and creating strong lexical communicative relations in typical speech situations;

3) varying situational stage - teaching to combine familiar vocabulary in different contexts in new ways. All topics learnt by foreign students at the lessons of Russian and Kazakh can be subdivided as follows: "A Man and his Social Environment", "Nature", "Countries and Travelling", "Books", "Politics", "Economics", etc.

Learning these topics prepares students to a more complicated stage - getting education in Russian or Kazakh.

The main stages of working on vocabulary include:

1) familiarizing with new vocabulary (including semantization);

2) reinforcement;

3) development of skills of using vocabulary in different forms of oral and written communication. 
What does it mean "to master a word"? It means that you are aware of its meaning, form (its pronunciation and visual image), its capacity for coming into relations with other words (semantic, grammatical). This also means mastering word building, inflexion and word use in speech. In a graphic form it can be presented as follows: relation of a foreign word to the notion, to the word in the native language, its multiple morphological and syntactic relations - all this makes the process of mastering vocabulary complicated and labor-intensive. The method of the semantization of lexical units implies definite form of arranging material by a teacher, as well as communicative form of its presentation to students.

Language teachers teach students to:

1. understand the meaning of the word;

2. listen to the pronunciation of the word;

3. pronounce words;

4. write words.

Before identifying the ways of vocabulary semantization in the course of teaching language to foreign students, students shall be suggested active vocabulary used for expressing ideas in oral or written communication, which is used for perceiving oral or written information.

It is impossible to teach semantics only. A teacher shall create paradigmatic, syntactic and associative relations.

Discovering the meaning of a word (semantization) can be performed in non-translation and translation ways.

The non-translation ways of semantization include:

1) showing objects, gestures, actions, pictures, drawings, slides, etc.,

2) determining the meaning of the word based on one's notes and by guessing;

3) semantization with the help of synonyms and antonyms.

The translation ways of semantization include:

1) replacement of a word with an appropriate equivalent from the native language;

2) translation-interpretation, where, apart from the equivalent, the information about the coincidence or difference of the meaning is provided.

The choice of the ways of semantization depends on the word characteristics and its belonging to a productive or receptive minimum, on the learning stage, as well as on the language level of the students.

The formation of lexical skills is connected with the solidity of the command of vocabulary. In order to ensure vocabulary reinforcement by the students, they shall be suggested exercises developing the skills of using lexical material in listening, speaking, reading and writing. These exercises imply the following peculiarities:

1) they shall perform explaining and controlling function;

2) new lexical units shall be presented in familiar lexical surrounding;

3) exercises shall include complex actions developing creative abilities of the students.

With time, the increasing complexity activates the thinking processes of the students forming connected utterances. The differentiated approach implies differentiation between learning activities as per their complexity degree, differentiation of the conditions under which these assignments are to be fulfilled, as well as differentiation of the forms of control over the fulfillment of these assignments (Butova, 2001, p. 174).

Within the framework of the specified approaches, general didactic (principle of subjectivity, reflection, visualization, solidity, activity, etc.) and methodological principles (principle of reliance on lexical rules, principle of rational relation between algorithmic, semi-heuristic, heuristic learning activities in the course of teaching vocabulary, as well as the principle of lexical strategies) are implemented.

The below exercises can be offered:

1) Exercises on differentiation:

- find in the text the words referring to one topic (or read them out loud);

- group the words on this basis;

- find antonyms to these words;

- provide situations where new vocabulary can be used.

2) Exercises intended to develop word building and contextual deduction:

- determine the meaning of unfamiliar words derived from familiar roots;

- complete the sentence;

- $\quad$ expand the sentence;

- reduce the sentence.

3) Exercises for replacement:

- replace the underlined words with synonyms; 
- replace the underlined words with antonyms;

- replace answers to questions;

- alter the last utterance in the dialogue leaving the answer positive.

4) Exercises at the collocation level.

- $\quad$ make up, find collocations to the suggested vocabulary;

- $\quad$ find 3-4 definitions to the nouns (3-4 adverbs to verbs), etc.

- join scattered words to make up idioms.

5) Exercises at the sentence level:

- answer the questions;

- $\quad$ ask questions to the italicized words;

- complete the following sentences;

- $\quad$ join sentences to form a text;

- think of and give a title to a drawing;

- $\quad$ compare the characters;

- compose a story using the given vocabulary;

- describe a picture.

At the initial stage, the vocabulary is introduced orally; at the intermediate and advanced stages, a written support is required.

Vocabulary teaching includes working with a dictionary. Students shall be able to use a dictionary, to find words quickly, to know the alphabet of the language learnt. Nowadays, many students use electronic dictionaries, which allow them not only to rapidly translate words, but also to listen to their pronunciation.

Before the new vocabulary is presented, the teacher can be recommended to review the new words in order to select the appropriate semantization method for vocabulary units, make up comments to the new words, select exercises for reinforcing new lexical material.

Meanwhile, among linguistic and communicative abilities there can be distinguished the following abilities (Golubeva, 1989, pp. 108-109):

- retain lexical units in long-term memory;

- distinguish aurally the phonetic composition of an utterance and associate it with an appropriate meaning;

- imitate articulation of lexical units;

- $\quad$ perform verbal prediction;

- discover the laws of word building, words morphological structure, their combinability, stylistic and semantic differentiation.

\section{Conclusions}

Teaching of vocabulary is a very interesting process making foreign students analyze speech, group words, get education in Russian or Kazakh language.

The language component includes the main structural elements and provides for the formation of the students':

- lexical knowledge (phonetic and graphic form of a word; word semantics; relative value of the word; ability of the word for having synonyms, antonyms, homonyms, paronyms, stylistic and sociocultural connotation; syntactic and lexical combinability of words; word building rules; types of dictionaries; basic notions related to the word structure; similarities and/or differences between the lexical systems of the native and the foreign language);

- lexical skills (receptive and reproductive as per the types of speech activity);

- lexical awareness (ability of the speaker to operate phonetic, grammatical, lexical skills in their close interrelation).

Teaching vocabulary of the Russian and Kazakh languages to foreign students allows to establish solid and flexible communicative relations. The formed lexical competence includes skills of prompt remembering of words and selecting words based on the semantic and sociocultural characteristics. Vocabulary unites the acts of speaking and understanding and is the leading means of communication, either orally or in written form. The suggested exercises enrich students' vocabulary, develop interrelated sides of speech activity. All the above mentioned types of semantization constitute a unified whole. Different ways of semantization are set forth for methodological purposes to ensure fast achievement of the desired result.

\section{References}

Baryshnikov, N.V. (2000). Osobennosti mezhkul'turnoy kommunikatsii pri nesovershennom vladenii inostrannym yazykom [Peculiarities of Cross-Cultural Communication at Imperfect Language Skills]. In Sbornik nauchnykh statey 
"Obuchenie mezhkul'turnoy kommunikatsii v razlichnykh usloviyakh" [Collection of scientific articles "Teaching CrossCultural Communication in Various Conditions"] (pp. 5-12). Pyatigorsk.

Butova, L.V. (2011). Diferentsiyovaniy pidkhid u navchanni angliys'koï movi [Differentiated Approach in Teaching English]. Tavriys'kiy visnik osviti, 4(36), 174-178.

Brown, C., \& Yule, G. (1983). Discourse Analysis (pp. 24-57). Cambridge.

Van Ek, J.A., \& Trim, J.L. (1990). Threshold 1990. Council of Europe. Cambridge university Press.

Galskova, N.D., \& Gez, N.I. (2008). Teoriya obucheniya inostrannym yazykam. Lingvodidaktika i metodika [Theory of Teaching Foreign Languages. Lingvodidaktika and metodika]. Moscow: Academia.

Golubeva, E.A. (1989). Sposobnosti i sklonnosti: kompleksnye issledovaniya [Abilities and Inclinations: Comprehensive Research]. Moscow: Pedagogika.

Dijk, T.A. van, \& Kinch, V. (1988). Strategiya ponimaniya svyaznogo teksta [Strategy for Understanding Connected Text]. Novoye $v$ zarubezhnoy lingvistike. Vyp. 23. Kognitivnye aspekty yazyka [New in Foreign Linguistics: Issue 23. Cognitive Aspects of the Language]. Moscow.

Ignatova, E.R., \& Tolmacheva, D.S. (2012). Formirovanie grammaticheskikh navykov pri obucheniyu russkomu yazyku inostrannykh studentov [Formation of Grammar Skills When Teaching Russian to Foreign Students]. Journal of science of HNUE, 57, 75-78.

Kitaigorodskaya, G.A. (2009). Intensivnoe obuchenie inostrannym yazykam. Teoriya i praktika [Intensive Training in Foreign Languages. Teory and Practice]. Moscow: Vysshaya shkola.

Kommunikatsiya i obuchenie inostrannym yazykam [Communication and Foreign Language Teaching], (1970). Minsk: Vysheishaya shkola

Krupchenko, A.K., \& Kuznetsova, A.N. (2015). Osnovy professional'noy lingvodidaktiki: Monografiya [Fundamentals of Professional Lingua-Didactics: Monographic]. Moscow: APKiPPRO.

Kubriakova, E.S., \& Aleksandrova, O.V. (1997). Vidy prostranstva teksta i diskursa [Types of Space, Text and Discourse]. In Kategorizatsiya mira: prostranstvo $i$ vremya [World Categorization: Space and Time] (pp. 19-21). Moscow: Nauka.

Mitrofanova, O.D., Kostomarov, V.G., Viatutnev, M.N., Sosenko, E.Yu., \& Stepanova, E.M. (1990). Metodika prepodavaniya russkogo yazyka kak inostrannogo [Methods of Teaching Russian as a Foreign Language]. Moscow: Russkiy Yazyk.

Munby, J. (1978). Communicative Syllabus Design. Cambridge: Cambridge University Press.

Common European Framework of Reference for Languages: Learning, Teaching, Assessment. Department of Language Policy, Strasbourg. The Council of Europe (French and English versions), 2001. Moscow Linguistic University (Russian version), 2005.

Passov, E.I., Kibereva, L.V., \& Kolarova, E. (2007). Kontseptsiya kommunikativnogo inoyazychnogo obrazovaniya (teoriya $i$ ee realizatsiya). Metodicheskoe posobie dlya rusistov [Concept of Communicative Foreign language Education (Theory and Its Implementation). Resource Book for Russianists]. Saint Petersburg: Zlatoust.

Passov, E.I., \& Kuzovlev, N.E. (2010). Urok inostrannogo yazyka [Lesson of Foreign Language]. Rostov on Don: Feniks; Moscow: Glossa-Press.

Perestoronina I.L. (2003) Formirovanie yazykovoi kompetentsii pri obuchenii leksike vtorogo inostrannogo yazyka: na primers anglo-frantsuzskih kognatov [Formation of linguistic competence in teaching vocabulary a second foreign language: primers on the Anglo-French cognates] $\mathrm{PhD}$ thesis. Moscow.

Schmitt, N. (2000). Vocabulary in Language Teaching. New York: Cambridge University Press.

Ter-Minasova, S.G. (2008). Yazyk i mezhkul'turnaya kommunikatsiya: Ucheb. posobie [Language and Cross-Cultural Communication: Teaching Aid]. Moscow: Slovo.

Uspenskiy, M.B. (2004). Kurs sovremennogo russkogo yazyka v pedagogicheskom vuze: Ucheb. Posobie [Course of Modern Russian Language at Pedagogical University: Teaching Aid]. Moscow: Publishing office of Moscow Psychological and Social Institute; Voronezh: NPO "MODEK".

Shamov A.N. (2005) Kognitivnyi podhod k obucheniu leksike: modelirovanie i realizaciya: bazovyi kurs nemetskogo yazyka [The cognitive approach to learning vocabulary: modeling and realization: German language basic course]. PhD thesis. N. Novgorod.

Shamov A.N. (2007) Leksicheskie navyki ustnoi rechi i chteniya - osnova semanticheskoi kompetentsii obuchaemyh [Lexical skills of speaking and reading - the basis of the semantic competence of trainees]. Inostrannye yazyki v shkole, 4: 19-21.

Shchukin, A.N. (2007). Lingvodidakticheskiy entsiklopedicheskiy slovar' [Linguo-Didactic Encyclopaedic Dictionary]. Moscow: Astrel: AST: Khranitel.

Wolpers, M., Kirschner, A., Scheffel, M., Lindstaedt, S., \& Dimitrova, V. (2010). Sustaining TEL: From Innovation to Learning and Practice. In Proceedings of the 5th European Conference on Technology Enhanced Learning. Barcelona, Spain: Springer. 